\title{
The role of service marketing mix on the decision to choose a school: an empirical study on elementary schools
}

\author{
Ahmad Syarief Iskandar ${ }^{*}$, Burhan Rifuddin Ilham, Dodi Ilham, Rahmat Rahmat \\ Institut Agama Islam Negeri Palopo, Indonesia
}

\begin{tabular}{l} 
Article Info \\
\hline Article history: \\
Received Aug $16^{\text {th }}, 2021$ \\
Revised Sept $06^{\text {th }}, 2021$ \\
Accepted Oct $19^{\text {rd }}, 2021$ \\
\hline
\end{tabular}

\section{Keyword:}

Service marketing mix

Decision making

Elementary school

\begin{abstract}
This study aims to analyze the effect of the service marketing mix, including Product, Price, Place, Promotion, People, Process, and Physical Evidence, on parents' decision-making in choosing elementary schools. This type of research is descriptive analysis. The research sample is parents or guardians of elementary school students totaling 321 people in Palopo; the sampling technique used is a simple random sampling method. The data collection technique used was an online questionnaire via Google Form. The data analysis method used is Structural Equation Modeling (SEM) analysis with data processing tools using SmartPLS 3.0 software. The results of data analysis show that: Product, Price, Place, Promotion, People, Process, and Physical Evidence have a positive and significant effect on the decision to choose an elementary school in Palopo. The novelty of this research is the relationship model of the service marketing mix to the decision to choose an elementary school.
\end{abstract}

\section{Corresponding Author:}

Ahmad Syarief Iskandar,

Institut Agama Islam Negeri Palopo

Email: ahmadsyariefiskandar@gmail.com

\section{Introduction}

According to Abzari et al. (2014), Primary education is the most critical phase in a child's life cycle. In this phase, the foundation of knowledge in reading, writing, arithmetic, and the child's personality is formed. Therefore, it is natural that parents are very selective in deciding the choice of schools in primary education. Every parent wants to give the best for their children. Unlike past parents who were easy to decide on school choices, today's parents tend to be careful in choosing elementary schools for their children because of the broad knowledge of public education and the large variety of school choices available such as excellent public schools, international standard schools, private schools, national schools, religion-based private schools and the latest model schools, namely the natural school.

According to Brocato et al. (2015), before sending children to school, pay attention to student profiles, a kind of design for the formation of students targeted by the school. A good student profile includes four things, including producing students who have special skills, life skills, leadership skills, and at the same time have an entrepreneurial spirit. After believing that the target school has a student profile as described above, then the curriculum, the quality of human resources, school facilities, costs, and location will be examined. According to (Ahmed et al., 2014; Bilgin et al., 2018; Brocato et al., 2015)

The behavior of parents in choosing a school is the same as the behavior of consumers in deciding to buy. Many factors influence consumer behavior. Consumer behavior is the process of making each individual's 
decisions and activities in evaluating, obtaining, using, or managing goods or services. According to (Ahmed et al., 2014; Bilgin et al., 2018; Brocato et al., 2015) explained that four things underlie the buying decisionmaking process, namely product, price, location, and promotion, specifically for educational services, it cannot be separated from discussions about products (educational activities), prices (tuition fees), promotions, places or locations, people or the quality of teachers and administrative staff, learning processes or methods, and facilities. The phenomenon of the emergence of natural schools to the interest of parents deciding to send their children to this place is an exciting thing to examine and what service marketing mix needs to be improved by the school. In this case, the marketing mix of educational services is the element of an educational organization that the organization can control in communicating with students. Currently, education is a basic need for every individual. According to (Abzari et al., 2014; Ardiansyah et al., 2020; Almohaimmeed et al., 2019); education is every effort, influence, protection, assistance given to a child aimed at the maturation of the child, or more accurately, helping the child to be sufficient, capable of carrying out his life duties. In Indonesia, formal education is mainly divided into several levels, namely primary education, secondary education, and higher education. The most crucial educational phase for a child's life cycle is primary education.

According to (Bilgin et al., 2018; Brocato et al., 2015), In the era of education 4.0 and there are many choices of schools in the Kebumen sub-district, parents must be even wiser in determining school choices for the future of their sons and daughters. Currently, general education alone is considered not sufficient to meet the basic education needs of children. Currently, globalization has encouraged the emergence of very competitive competition in educational services so that there are more and more choices of schools available. For this reason, primary education institutions are required to use and develop their business in various strategic marketing ways through the ability to identify the target market that is the consumer of primary education institutions. The quality of educational institutions is indeed essential in influencing the assessment of parents. Still, parents should not forget other factors such as safety, location, and school environment. According to (Ahmed et al., 2014; Bilgin et al., 2018; Brocato et al., 2015), marketing of educational services offers services with a marketing mix of marketing tools known as the 7Ps, namely product, price, place, promotion, people, physical evidence and process.

The addition of service marketing mix elements is done because services have different characteristics from products. According to (Almohaimmeed et al., 2019; Ahmed et al., 2014; Bilgin et al., 2018; Brocato et al., 2015) revealed that there are four characteristics possessed by services, namely, intangible (intangibility), inseparable (inseparability), varied (variability), and perishability. These elements influence each other so that if one is properly organized, it will affect the overall marketing strategy.

According to (Clark et al., 2017; Constantinides et al., 2011; Ceyhan et al., 2019), In the marketing strategy, especially from internal schools, it is necessary to pay attention to how to apply the service marketing mix in the field of primary education. This service marketing mix strategy will determine the community's decision in choosing a school. So that the school must optimize the marketing mix strategy of suits, first, design educational service products that are by the school's vision, mission, and characteristics. Product is a general concept that also includes fulfilling consumer needs related to goods, services, or ideas. According to Bilgin et al. (2018) Brocato et al. (2015), products in educational services are the same as educational programs implemented by the school. Second, determine the price or price that is a monetary unit exchanged to obtain ownership rights or the use of an item or service. In the context of educational services, price is all costs incurred by students to obtain educational services.

Planning a strategy for determining the cost of education charged to the guardians of students must be by the operational needs of education providers. Third, determining the place or location of the school needs to be considered so that it is easy to access or reach by students and their guardians. Location selection is essential in school decision-making. Fourth, determine the promotion strategy. A promotion from the school is one source of information that can influence parents' decisions in choosing a school for their children. Fifth, managing people or human resources (HR) who hold the central control of the learning process in schools. In the world of Human Resources (HR), education consists of teachers and employees. Human resources are the main assets that function as service providers in service marketing, which significantly affect the quality of services provided (Adam, 2014: 96). To compete, good human resource management will contribute to improving the quality of educational service products - sixth, organizing a quality educational process. According to Kotler and Keller (2012:47), the process element has the meaning of an effort by the company to carry out activities to meet the needs and desires of its customers. Seventh, managing physical evidence or physical facilities properly. Physical evidence or facilities are also the most critical factors in influencing consumer behavior in choosing schools. Good management of physical facilities will provide a sense of security and comfort during the teaching and learning process and other activities within the school 
environment.The purpose of the study was to determine the effect of the product, price, place, promotion, people, process, and physical evidence partially on the decision to choose an elementary school in Palopo.

\section{Marketing}

Marketing has a substantial contribution to the company's external environment. According to the concept put forward by according (Abzari et al., 2014; Ardiansyah et al., 2020; Almohaimmeed et al., 2019), Marketing is a societal process by which individuals and groups obtain what they need and want through creating, offering, and freely exchanging products and services of value with others.Service is always identified with personal service and has an intangible or form nature. So far, many service marketing experts have tried to define the meaning of service, according to (Abzari et al., 2014; Ardiansyah et al., 2020) state that service is any act or performance that one party can offer to another, which is essentially intangible and cannot result in the ownership of anything. Its production may or may not be linked to a physical product. Consumer behavior is the study of how individuals, groups, and organizations select, purchase, use, and dispose of goods: services, ideas, or experiences to satisfy their needs and wants.

\section{Buying decision}

According to (Clark et al., 2017; Constantinides et al., 2011; Ceyhan et al., 2019) Decision making is the process of selecting from two or more alternative options. In other words, a decision is a choice of several possible alternatives. According to (Jamali, M., \& Khan, R., 2018; Karman, M. A., 2015; Moran et al., 2011). The consumer decision-making process is through the following sequence: 1 . Recognition of needs According to (Moran et al., 2011). Need recognition is the first stage of the buyer's decision-making process in which the consumer recognizes a problem or need. These needs can be felt through internal and external stimuli. 2 . Information Search, Information search before buying begins when consumers feel a need to be met by buying and consuming a product. Past experiences provide consumers with information to make choices today. On the other hand, if consumers do not have experience, the consumer's purchase decision is a decision taken by a prospective buyer regarding the certainty of buying or not

The service marketing mix is a set of marketing tools known as the 7Ps: product, price, place, promotion, process, and physical evidence used by companies to influence consumer responses. For service marketing mix elements according to (Dutta et al., 2016; Hutter et al., 2013; Jamali, M., \& Khan, R., 2018; Karman, M. A., 2015; Moran et al., 2011). can be explained as follows: 1. Product, The product is the whole concept of an object or process that benefits consumers. What needs to be considered in the product is that consumers do not only buy the physical product from the product itself but also by its benefits and value, which is called the offer .2. Price: The price strategy is very significant in purchasing decisions at the consumer level and affects the product image. Strategic policies and tactics such as price levels, payment terms, and discounts are taken into consideration by consumers choosing the products offered 3. Place in services is a combination of location and decisions on distribution channels related to delivering services to consumers and where the strategic location is. 4. Promotion, Promotion includes various methods for communicating the benefits of services to potential customers. These methods usually include advertising, sales promotion, personal selling, and public relations to introduce and present the service itself. 5. Regarding service marketing, people who directly handle consumers in marketing activities are certainly very influential by their serving staff and the length of waiting during the production process. 6 . The process is all the procedures, mechanisms, and customs in which a service is created and delivered to customers, including policy decisions about some customer involvement and personal discretion of employees.7. Physical Evidence, Physical evidence is the physical environment where services are created and directly interacted with by consumers, according to (Clark et al., 2017; Karman, M. A., 2015; Moran et al., 2011). There are two types of physical evidence, namely essential evidence and peripheral evidence.

\section{Method}

This research is a quantitative descriptive analysis. The sample of this study was the parents or guardians of elementary school students totaling 321 people; the sampling technique used was simple random sampling method - data collection techniques used using online questionnaires via Google Form. The data analysis method used is Structural Equation Modeling (SEM) analysis with data processing tools using SmartPLS 3.0 software. The variables are analyzed, it is necessary to explain the operational definitions of each variable, namely: 1) The independent variable in this study is the service marketing mix (X), including the following: Product, Price, Place, Promotion, People, Process, Physical Evidence; 2) The dependent variable of this study is the decision to choose a school (Y). 


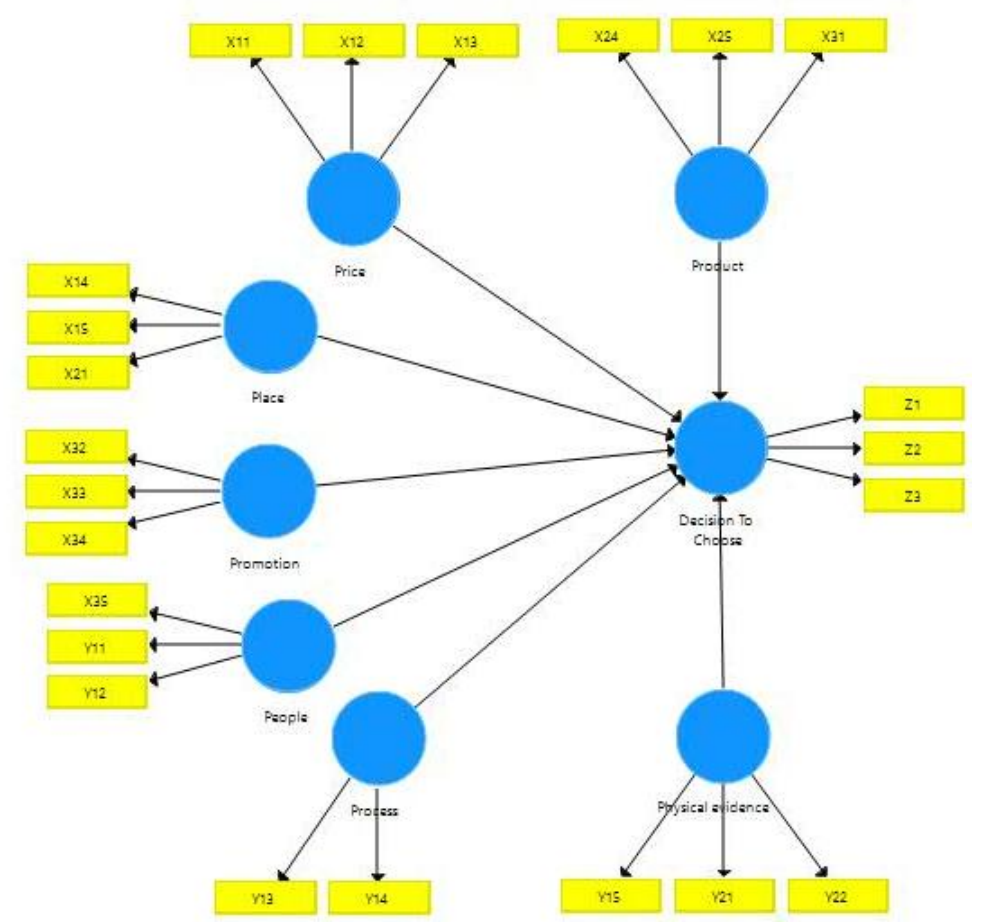

Figure 1. Research Framework

This study took seven variables to study, namely product, price, place, promotion, people, and Physical Evidence. This research was conducted by distributing questionnaires to parents of students who sent their children to elementary school in Palopo. To provide a clear picture of this research, a framework of thought is drawn up as shown below:

Based on the research framework in Figure I, a hypothesis is formulated, which is a temporary answer to the formulation of the research problem, namely:

H1: Product has a significant effect on the decision to choose an elementary school

H2: Price has a significant effect on the decision to choose an elementary school

H3: Place has a significant effect on the decision to choose an elementary school

H4: Promotion has a significant effect on the decision to choose an elementary school

H5: People has a significant effect on the decision to choose an elementary school

H6: Process has a significant effect on the decision to choose an elementary school

H7: Physical evidence has a significant effect on the decision to choose an elementary school

\section{Result and Discussion}

Part of the analysis of the results of this study is testing the validity and reliability of the instrument and testing the hypothesis where at the stage of preparing the questionnaire, one of the criteria for a good questionnaire is the validity and reliability of the questionnaire.

Table 1. Cronbach's Alpha, Composite Reliability, and Average Variance Extracted (AVE)

\begin{tabular}{lllll}
\hline Variables & $\begin{array}{l}\text { Cronbach's } \\
\text { Alpha }\end{array}$ & Rho_A & $\begin{array}{l}\text { Composite } \\
\text { Reliability }\end{array}$ & AVE \\
\hline Product & 0.856 & 0.877 & 0.872 & 0.532 \\
\hline Prices & 0.868 & 0.866 & 0.899 & 0.596 \\
\hline Place & 0.853 & 0.857 & 0.895 & 0.631 \\
\hline Promotion & 0.864 & 0.866 & 0.893 & 0.596 \\
\hline People & 0.853 & 0.859 & 0.895 & 0.631 \\
\hline Process & 0.864 & 0.866 & 0.894 & 0.596 \\
\hline Physical evidence & 0.853 & 0.855 & 0.895 & 0.633 \\
\hline Decision to Choose & 0.864 & 0.866 & 0.899 & 0.594 \\
\hline
\end{tabular}


A constructor variable is reliable or has a high level of consistency and accuracy if it gives a Cronbach Alpha value above 0.60 (Ghozali, 2009). The results of reliability testing in this study indicate that all research variables are reliable.Therefore, the variables in this study were valid and reliable. The results of the validity and reliability tests can be seen in Table 1 .

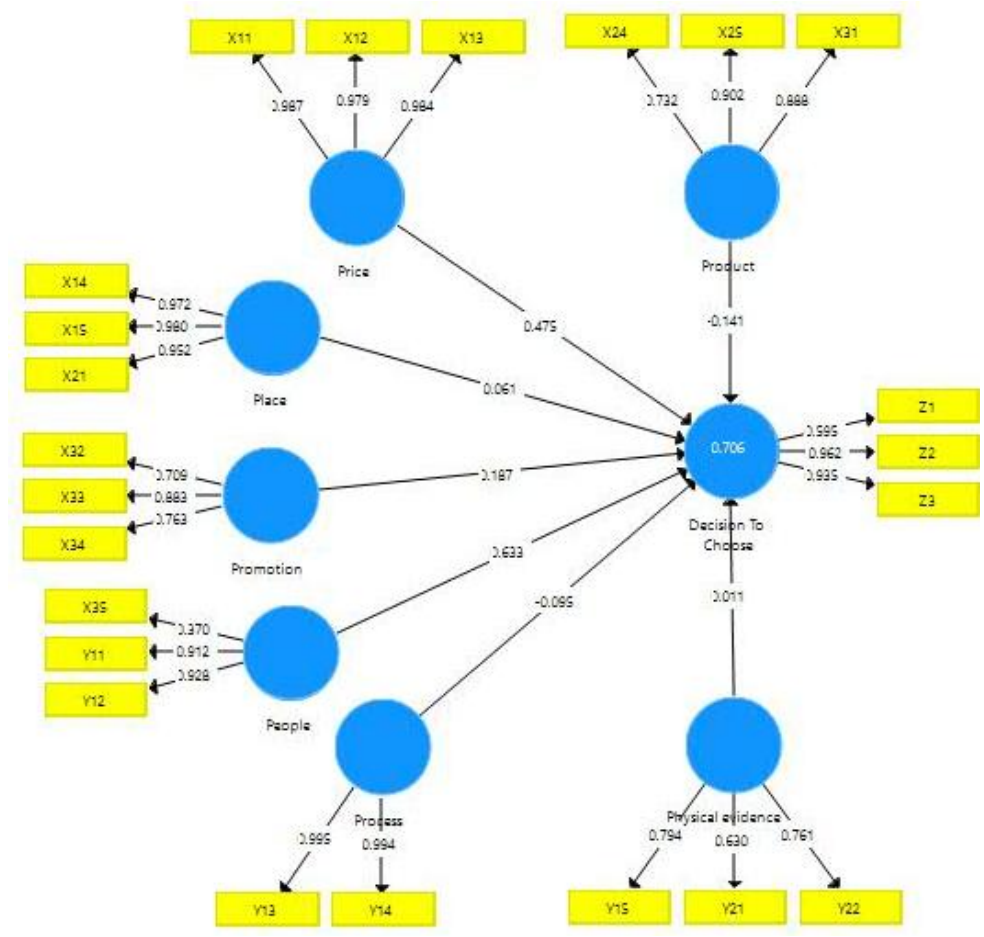

Figure 2. Validity Testing

The validity test is measured from the AVE (Average Variance Extracted) value. The AVE value $>0.5$ means that the variable can describe the variance of each indicator. The reliability test was measured from the composite reliability value. Composite reliability value $>0.7$ means that all question items in this study are reliable.

Table 2. $R$ Square

\section{R Square $\quad$ R Square Adjusted}

\begin{tabular}{lll}
\hline Decision to Choose & 0.706 & 0.682 \\
\hline
\end{tabular}

The R-square value explains the effect of exogenous (independent/independent) variables in explaining endogenous (dependent/bound) variables. The value of $\mathrm{R}$ Square can be seen in Table 2. This study has a relevant value where the product can explain $70.6 \%$ of the decision to choose variables, Price, Place, Promotion, People, Process, and Physical Evidence variables, while other factors explain 29.4\%.

Table 3. Hypotheses Testing

\begin{tabular}{cccc}
\hline Hypotheses & Relationship & P Values & Decision \\
\hline H1 & Product -> DTC & 0.000 & Supported \\
H2 & Price -> DTC & 0.001 & Supported \\
H3 & Place -> DTC & 0.000 & Supported \\
H4 & Promotion - > DTC & 0.002 & Supported \\
H5 & People -> DTC & 0.000 & Supported \\
H6 & Process -> DTC & 0.003 & Supported \\
H7 & Physical Evidence -> DTC & 0.000 & Supported \\
\hline
\end{tabular}


PLS path analysis test was performed using SmartPLS. The test results can be seen in Table 3.

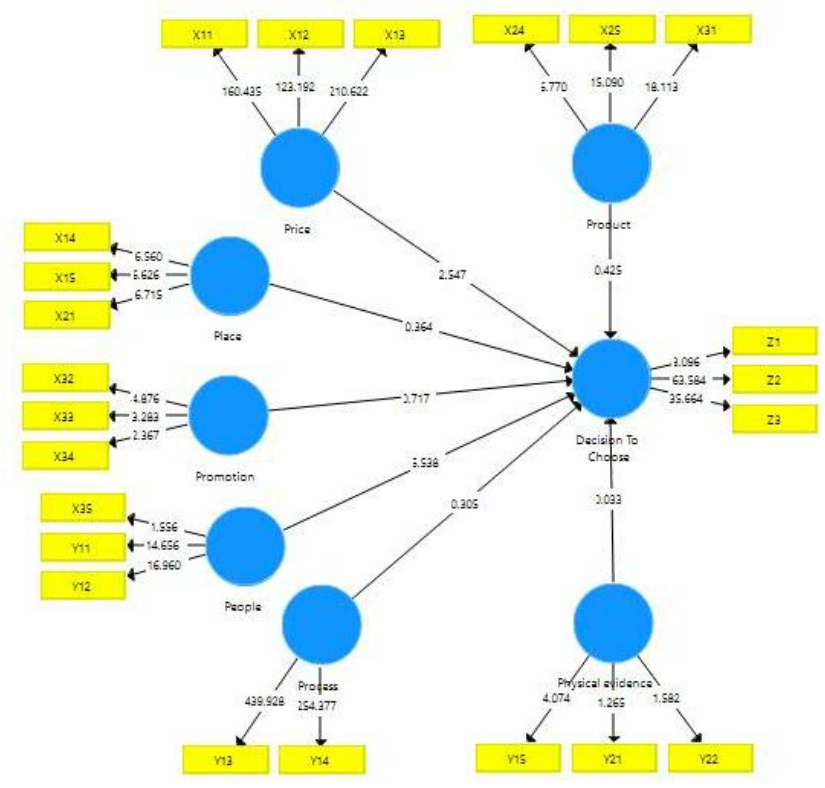

Figure 3. Hypotheses Testing

Product relationship to the decision to choose an elementary school

Based on the hypothesis analysis, the p-value is $0.000<0.050$, so it can be concluded that there is a significant relationship. Based on these results, it can be concluded that the product variable significantly influences the decision to choose a school. The results of this study are in line with previous research conducted by According Karman (2015); Moran et al. (2011), which states that the product can significantly affect the decision to choose the Nurul FikriSukodono Integrated Islamic Kindergarten school in Sidoarjo. It shows that the higher the quality of the product (educational program) offered, the higher the decision to choose a school. Therefore, actions that need to be considered by the school must be committed to maintaining and improving the quality of educational products or programs because a quality product is expected to increase the number of elementary school students.

\section{Price's relationship to the decision to choose an elementary school}

Based on the hypothesis analysis, the p-value is $0.001<0.050$, so it can be concluded that there is a significant relationship. Based on these results, it can be concluded that the price variable significantly influences the decision to choose a school. The results of this study are in line with previous research conducted by According Ceyhan et al. (2019); Crittenden et al. (2015); Dutta et al. (2016); Hutter et al. (2013); Jamali, M., \& Khan, R. (2018); Karman, M. A. (2015); Moran et al. (2011), which states that price can have a significant effect on the decision to choose a school.Actions that need to be considered by the school are that they still have to consider every determination of the number of fees incurred by parents for educational programs because costs are directly proportional to the quality of education. The higher the cost, the higher the quality of education offered. Meanwhile, to provide security and convenience for parents in payments, it is necessary to consider payment through bank transfers. So that it is expected to increase the number of elementary school students

\section{Place's relationship to the decision to choose an elementary school}

Based on the hypothesis analysis, the p-value is $0.000<0.050$, so it can be concluded that there is a significant relationship. Based on these results, it can be concluded that the place variable significantly influences the decision to choose a school. The results of this study are not in line with previous research conducted by (Hutter et al., 2013; Jamali, M., \& Khan, R., 2018; Karman, M. A., 2015; Moran et al.,2011) which states that place (location) has a significant effect on parents' decisions in choosing schools. Actions that need to be considered by the school are to provide convenience for parents or prospective customers who will visit to reach the location by developing a website and more precise directions. So that it will increase the number of elementary school students

\section{Promotion's relationship to the decision to choose an elementary school}

Based on the hypothesis analysis, the $p$-value is $0.002<0.050$, so it can be concluded that there is a significant relationship. Based on these results, it can be concluded that the promotion variable does not significantly 
influence the decision to choose a school. The results of this study are in line with previous research conducted by Ceyhan et al. (2019); Crittenden et al. (2015); Dutta et al. (2016); Hutter et al. (2013); Jamali, M., \& Khan, R. (2018); Karman, M. A. (2015); Moran et al. (2011), which states that advertising and promotions have a positive and significant influence on purchasing decisions. The school's actions that need to be considered are increasing school promotion activities with the current communication media (internet). So it is hoped that more people will know about elementary school

\section{People's relationship to the decision to choose an elementary school}

Based on the hypothesis analysis, the $p$-value is $0.000<0.050$, so it can be concluded that there is a significant relationship. Based on these results, it can be concluded that the people variable has a significant influence on choosing a school. This study is not in line with the results of previous research conducted by Purwanto et al. (2021); Zehrer et al. (2012), with the results that people have a significant influence partially and simultaneously on the decision to choose entrepreneur-based schools in elementary schools. The action that needs to be considered by the school is to continue to improve the quality of its human resources by providing training and education so that it will improve the service process to parents and students.

\section{Process relationship to the decision to choose an elementary school}

Based on the hypothesis analysis, the p-value is $0.003<0.050$, so it can be concluded that there is a significant relationship. Based on these results, it can be concluded that the process variable significantly influences the decision to choose a school. The results of this study are not in line with previous research conducted by Crittenden et al. (2015); Dutta et al. (2016); Hutter et al. (2013); Jamali, M., \& Khan, R. (2018); Karman, M. A. (2015); Moran et al. (2011). which states that the process variable has a significant influence on parents' decisions in choosing primary schools. Actions that need to be considered by the school are to continue and provide the maximum possible process (service) to parents so that parents feel served and create a good relationship with parents of students.

\section{Physical evidence relating to the decision to choose an elementary school}

Based on the hypothesis analysis, the $\mathrm{p}$-value is $0.000<0.050$, so it can be concluded that there is a significant relationship. Based on these results, it can be concluded that the physical evidence variable significantly influences the decision to choose a school. This study is not in line with the results of previous studies conducted by Nyangau et al. (2012);Paladan et al. (2018); Purwanto et al. (2020); Purwanto et al. (2019); Purwanto et al. (2021); Zehrer et al. (2012). with the results of physical evidence has a significant influence partially and simultaneously on choosing a school. Actions that need to be considered by the school are to provide facilities and infrastructure that are comfortable, clean and provide adequate facilities and infrastructure considering the number of students who are constantly increasing every year so that it will create a sense of comfort and trust for parents because they have chosen primary school.

\section{Conclusion}

From the results of the discussion of the data presented in the previous section, it can be concluded that product has a significant effect on the decision to choose, the price has a significant effect on the decision to choose, the place has a significant effect on the decision to choose, the promotion has a significant effect on the decision to choose, people have a significant effect on the decision to choose an elementary school, the process has a significant effect on the decision to choose an elementary school,physical evidence has a significant effect on the decision to choose an elementary school. The results of simultaneous hypothesis testing have obtained that product, price, place, promotion, people, process, and physical evidence together significant effect on the decision of parents to choose a primary school. The influence of these seven variables on the parents' decision to choose a primary school is quite significant. The results of these conclusions certainly have implications for the condition of the object of research so that suggestions can be made for its development, including (1) researchers suggest that further research be carried out that affects purchasing decisions or product or service selection that are outside this model such as positioning and segmentation or factors other than a marketing strategy. (2) continue to carry out and improve jacket marketing mix activities that have a significant and influential effect on the decision to choose primary schools. (3) the Kebumen Elementary School must carry out promotional methods in new and more attractive ways, such as advertising through newspapers, introducing schools from various kindergartens, and holding exhibitions about schools. 


\section{References}

Abzari, M., Ghassemi, R. A., \&Vosta, L. N. (2014). Analyzing the effect of social media on brand attitude and purchase intention: The case of Iran Khodro Company. Procedia-Social and Behavioral Sciences, $143,822-826$.

Ardiansyah, F., \&Sarwoko, E. (2020). How social media marketing influences consumers purchase decision: A mediation analysis of brand awareness. JEMA: JurnalIlmiahBidangAkuntansi Dan Manajemen, 17(2), 156-168.

Almohaimmeed, B. M. (2019). The Effects of Social Media Marketing Antecedents on Social Media Marketing, Brand Loyalty and Purchase Intention: A Customer Perspective. Journal of Business and Retail Management Research, 13(4).

Ahmed, M. A., \& Zahid, Z. (2014). Role of social media marketing to enhance CRM and brand equity in terms of purchase intention. Asian Journal of management research, 4(3), 533-549.

Bilgin, Y. (2018). The effect of social media marketing activities on brand awareness, brand image, and brand loyalty. Business \& Management Studies: An International Journal, 6(1), 128-148.

Brocato, E. D., White, N. J., Bartkus, K., \&Brocato, A. A. (2015). Social media and marketing education: A review of current practices in curriculum development. Journal of Marketing Education, 37(2), 76-87.

Clark, M., Fine, M. B., \& Scheuer, C. L. (2017). Relationship quality in higher education marketing: the role of social media engagement. Journal of Marketing for Higher Education, 27(1), 40-58.

Constantinides, E., \& Zinck Stagno, M. C. (2011). Potential of the social media as instruments of higher education marketing: A segmentation study. Journal of marketing for higher education, 21(1), 7-24.

Ceyhan, A. (2019). The impact of perception-related social media marketing applications on consumers' brand loyalty and purchase intention. EMAJ: Emerging Markets Journal, 9(1), 88-100.

Crittenden, V. L., \& Crittenden, W. F. (2015). Digital and social media marketing in business education: Implications for student engagement.

Dutta, N., \& Bhat, A. (2016). Exploring the effect of store characteristics and interpersonal trust on purchase intention in the context of online social media marketing. Journal of Internet Commerce, 15(3), 239-273.

Hutter, K., Hautz, J., Dennhardt, S., \&Füller, J. (2013). The impact of user interactions in social media on brand awareness and purchase intention: the case of MINI on Facebook. Journal of Product \& Brand Management.

Jamali, M., \& Khan, R. (2018). The impact of consumer interaction on social media on brand awareness and purchase intention! Case study of Samsung. Journal of Marketing, 114.

Karman, M. A. (2015). The impact of social media marketing on brand equity toward the purchase intention of Starbucks Indonesia. IBuss Management, 3(2).

Moran, M., Seaman, J., \&Tinti-Kane, H. (2011). Teaching, Learning, and Sharing: How Today's Higher Education Faculty Use Social Media. Babson Survey Research Group.

Nyangau, J., \&Bado, N. (2012). Social media and marketing of higher education: A review of the literature. Journal of the Research center for educational technology, 8(1), 38-51.

Paladan, N. N. (2018). Higher Education Institutions Embracing Digital \& Social Media Marketing: A Case of Top 25 Universities in Asia \& Africa. Marketing and Branding Research, 5(3), 159.

Purwanto, A., Asbari, M., Santoso, T. I., Paramarta, V., \&Sunarsi, D. (2020). Social and Management Research Quantitative Analysis for Medium Sample: Comparing of Lisrel, Tetrad, GSCA, Amos, SmartPLS, WarpPLS, and SPSS. JurnalIlmiahIlmuAdministrasiPublik, 10(2), 518-532.

Purwanto, A., Asbari, M., Santoso, T. I., \& Haque, M. G. (2019). Marketing Research Quantitative Analysis for Large Sample: Comparing of Lisrel, Tetrad, GSCA, Amos, SmartPLS, WarpPLS, and SPSS. JurnalllmiahIlmuAdministrasiPublik, 9(2), 355-372.

Purwanto, A., Asbari, M., Santoso, T. I., Sunarsi, D., \& Ilham, D. (2021). Education Research Quantitative Analysis for Little Respondents. JurnalStudi Guru Dan Pembelajaran, 4(2), 335-350.

Purwanto, A., \&Sudargini, Y. (2021). Exploring Factors Affecting the Purchase Intention of Halal Food Products: An Empirical Study on Student Consumers. International Journal of Social and Management Studies, 2(4), 13-21. https://doi.org/10.5555/ijosmas.v2i4.46

Zehrer, A., \&Grabmüller, A. (2012). Social media marketing in tourism education: Insights into the development and value of a social network site for a higher education institution in tourism. Journal of Vacation Marketing, 18(3), 221-228. 